\title{
Neonatal Exposure to Citalopram Increases Pyramidal and Granular Cell Density in Dorsal Hippocampus of Male but not Female Adult Rats: A Quantitative Nissl Study
}

\author{
La Exposición Neonatal al Citalopram Aumenta la Densidad de las Células \\ Piramidales y Granulares en el Hipocampo Dorsal de Ratas Adultas Macho \\ pero no en Hembras: Un Estudio Cuantitativo con Tinción de Nissl
}

Heba M. Kalbouneh ${ }^{1}$ \& Loai A. Alzghoul ${ }^{2}$

KALBOUNEH, H. M. \& ALZGHOUL, L. A. Neonatal exposure to citalopram increases pyramidal and granular cell density in dorsal hippocampus of male but not female adult rats: A quantitative Nissl study. Int. J. Morphol., 37(2):576-583, 2019.

SUMMARY: Antidepressants use during pregnancy was associated with an increased risk of autism spectrum disorders. Animal models based on early life alterations in serotonin availability replicate some of the anatomical and behavioral abnormalities observed in autistic individuals. In recent years there has been a growing interest in the possible role of the hippocampus in autism. The aim of study is to examine the effects of neonatal antidepressant (CTM) exposure during a sensitive period of brain development on pyramidal and granule cells density of hippocampal formation. We examined the pyramidal and granular cells density of dorsal hippocampus using Nissl stained sections obtained from neonatal citalopram (CTM) exposed rats ( $5 \mathrm{mg} / \mathrm{kg}$, twice daily, s.c.), from postnatal day 8 to 21 (PN8-21), saline and non-exposed rats. The density of pyramidal cells was significantly increased by $10.2 \%$ in CA1, 10.6 \% in CA3 and $13.2 \%$ in CA4 in CTM treated compared with non-treated or saline treated animals $(\mathrm{p}<0.0001)$. The density of granule cells in the dentate gyrus was significantly increased by $12.0 \%$ in CTM treated compared with non-treated or saline treated animals $(\mathrm{p}<0.0001)$. These findings were obtained only from male rats, suggesting a sexual dimorphism in neural development after SSRI exposure. These data suggest that the neonatal exposure to CTM may induce long-lasting changes in the hippcampal formation in adults, and such effects appear to preferentially target males.

KEY WORDS: Antidepressant; Hippocampus; Autism; Cell density; Citalopram; neonatal exposure.

\section{INTRODUCTION}

Serotonin (5-HT) has long been postulated to play a trophic role in brain development. Serotonin influences the processes neurogenesis, neuronal differentiation, neuropil formation, axon myelination and synaptogenesis. Reuptake of 5-HT by the 5-HT transporter is a key control point in 5HT neurotransmission because it is the main route by which released 5-HT is cleared from the synapse (Lesch \& Gutknecht, 2005).

Manipulations of rodent brain 5-HT levels during early development, either through genetic means or perinatal drug treatments have been shown to produce the downstream effect of interfering with the formation of the barrel representation in the primary somatosensory cortex and promoting aggressive and/or anxiety-related behaviors ( $\mathrm{Xu}$ et al., 2004; Jennings et al., 2006).
Selective serotonin reuptake inhibitors (SSRIs) are the pharmacological treatment of choice for depression, anxiety, and obsessive-compulsive disorder. They are recommended for treatment of these disorders during pregnancy and lactation due relatively to the perceived low toxicity of the drug to mother, fetus, and infant (Cohen et al., 2004). However, SSRIs and their metabolites have been detected in both umbilical cord blood and amniotic fluid (Ewing et al., 2015). SSRIs exposure in utero has been associated with neonatal withdrawal syndrome, indicating that these drugs can penetrate fetal brain in utero at biologically significant levels (Sanz et al., 2005). In utero SSRI exposure was also found to influence fetal neurobehavioral development (Mulder et al., 2011). Chronic (PN8-21) neonatal exposure to citalopram, a potent and highly selective SSRI, results in lasting effects on

${ }^{1}$ Department of Anatomy and Histology, Faculty of Medicine, The University of Jordan, Amman, Jordan.

${ }^{2}$ Department of Physiology and Biochemistry, Faculty of Medicine, The University of Jordan, Amman, Jordan. 
serotonergic synthetic and synaptic clearance proteins. Furthermore, early exposure of rat pups to SSRIs (citalopram) produces increased locomotor activity and decreased sexual behavior in adult male rats (Maciag et al., 2006). The impairment of male sexual behavior and disruption of aggressive behaviors are consistent sequelae of early life antidepressant exposure across laboratories (reviewed in Vogel et al., 2000). In addition, manipulation of 5-HT during early development produces a reduction of tryptophan hydroxylase expression in midline subgroups of the raphe nuclear complex and a reduction in the density of Serotonin immunoreactive fibers in cortex (Weaver et al., 2010), and disturbs characteristic chemoarchitectural and electrophysiological brain features, including changes in raphe and callosal connections, sensory processing, and myelin sheath formation (Simpson et al., 2011).

Accumulating evidence indicates that manipulations of the 5-HT system during perinatal development can be one of the most important factors contributing to pervasive developmental disorders, especially to ASD. The role of serotonin in central nervous system development has encouraged the development of animal models based on early life alterations in serotonin availability (Whitaker-Azmitia, 2005; McNamara et al., 2008; Rodriguez-Porcel et al., 2011). The most consistent $5 \mathrm{HT}$ related finding in autistic disorder is hyperserotonemia (Janusonis, 2008). The relation of hyperserotonemia to 5-HT function in the brain and its role in the development of autism are still not understood. Experimentally, perinatal exposure to SSRIs has recently been shown to alter social behavior in adult rodents (Homberg et al., 2007; Simpson et al.), and those social behavioral abnormalities are more obvious in drug-exposed male vs. female animals. The neonatal exposure to SSRIs antidepressants in rats also results in sensory and social abnormalities that parallel many of those reported in ASD, and these effects of antidepressant exposure were more robust in males than in females (Rodriguez-Porcel et al.).

Autism spectrum disorders (ASDs) are thought to involve alterations in neural circuitry in different brain regions, including the hippocampus, an area critical for memory formation. The hippocampus is one of the key components of the neural system mediating emotion perception and regulation and is thought to be involved in the pathophysiology of autism (Groen et al., 2010).

The hippocampus is an integral component of the corticolimbic circuitry of the brain. The hippocampal formation is composed of the Cornu ammonis (areas CA1CA3), the dentate gyrus and the subicular complex. Accumulating evidence indicates that there are functional differences along the dorsal/ventral axis of the rodent hippocampus. The dorsal hippocampus primarily performs cognitive functions such as learning and memory, whereas the ventral hippocampus is more related to stress and emotion (Samuels \& Hen, 2011). Focusing on the hippocampus as a model brain region with a critical role in cognition and memory, we investigated the neuronal and glial density in the four specific areas of the dorsal hippocampus (CA1/CA3/ CA4 and DG) using the same hippocampal sections that were previously studied (Weaver et al.). In their original work (Weaver et al.; Rodriguez-Porcel et al.; Zhang et al., 2013), both male and female rat pups were exposed daily to either CTM or saline from PN8 to PN21, while a third group remained untreated. These rats were allowed to survive until adulthood. In this study, the cell packaging density of pyramidal cell layer (PCL) of CA subfields and granular cell layer (GCL) of the dentate gyrus were examined and compared in the three groups (CTM treated, saline and nontreated) using the Nissl staining technique.

\section{MATERIAL AND METHOD}

Nissl stained brain sections were obtained from Prof. Rick C. S. Lin (University of Mississippi Medical Center, Jackson, MS 39216). Treatment, dosing, and experimental subsets were previously described in their laboratory studies (Weaver et al.; Rodriguez-Porcel et al.; Zhang et al., 2013). Briefly, both female and male offspring of timed-pregnant Long-Evans rats (Harlan Sprague-Dawley, Indianapolis, IN) were used in their experiments. All procedures were approved by the UMMC Institutional Animal Care and Use Committee and complied with AAALAC and NIH standards. Shortly after the delivery, the offspring were selected and cross fostered to produce litters of 4-5 pups. The pups were tattooed for identification based on which treatment they would receive. Beginning on PN8, the pups were injected subcutaneously with citalopram (CTM; $5 \mathrm{mg} / \mathrm{kg}$, twice daily) (Toronto Research Chemicals (Toronto, Canada)) or saline in a volume of $0.1 \mathrm{ml}$ twice daily for 14 days (PN8-21), while a third group remained untreated. At PN28 pups were weaned and housed in groups of 2-3/cage under standard laboratory conditions with ad lib access to food and water. At $\mathrm{PN}>100$, four adult animals from each group were randomly chosen for perfusion and histological staining. Brains were cut with a freezing microtome at $40 \mu \mathrm{m}$, and sectioned in the coronal plane. Every sixth section was stained for Nissl substance using cresyl violet.

Measurements of Hippocampus: Nissl-stained samples were viewed using an Axio Lab.A1 microscope (Carl Zeiss, Gottingen, Germany) with $10 \times$ and $40 \times$ objectives and an attached ZEISS AxioCam ERc5s camera (Carl Zeiss, 
Gottingen, Germany). Images $(2560 \times 1920$ pixels $)$ were acquired from dorsal hippocampus using Zeiss ZEN microscope software. Data was collected from each of the four major dorsal hippocampus subdivisions: CA1, CA3, CA4 and the dentate gyrus at Bregma -3.96 and -2.40 . Two to three images were acquired from each subdivision per tissue section for the purpose of determining whether certain regions of the dorsal hippocampus are selectively affected by drug treatment. Images were exported into ImageJ (NIH, Bethesda, MD, USA) in tiff format for processing. Brightfield images were converted to grayscale. The background was subtracted to minimize the impact of the background. The density of the neurons and glia in PCL of CA14 and the GCL of dentate gyrus were measured at standard magnifications of 40X as described (Brackenbury et al., 2013) with some modifications. This magnification yielded terminal field dimensions that measured $280.69 \times 210.52 \mu \mathrm{m}$. The area of interest on $40 \times$ images was divided into $30 \times 30$ $\mathrm{mm}$ squares, and the number of neurons and glia within the PCL was counted within each square. In GCL, the area of interest was divided into $50 \times 50 \mathrm{~mm}$ squares. Ten squares were counted from at least one section per rat brain. The mean cell number in the test volume for all sections was then calculated after a calibration of the program for the specific type of microscope and microscope camera that have been used.

Statistical analysis: The statistical analysis was performed using the IBM SPSS Statistics for Windows, version 20 (IBM Corp, Armonk, NY, USA). Comparisons between groups were based on one-way analyses of variance (ANOVA). Bonferroni correction test was used for post hoc comparison between the different experimental groups. Values for $\mathrm{P}<0.05$ were regarded as statistically significant.

\section{RESULTS}

We found a significant increase of neuronal and glial packaging density in all hippocampal subfields and the dentate gyrus in male CTM-treated group compared with the non-treated or saline treated groups (Fig. 1). The quantitative analysis of neuronal and glial cell densities in PCL of CA1, CA3 and CA4, and the GCL of DG revealed an increase in cell density per unit volume for CTM treated group compared to saline and non treated groups (Fig.1BE). The cell density of PCL in CA1 was $26.47 \pm 0.41$ cells per $900 \mu \mathrm{m}^{2}$ (mean $\pm \mathrm{SE}$ ) in CTM treated rats compared to non-treated rats $(24.01 \pm 0.37$ cells), or saline-treated rats ( $24.25 \pm 0.38$ cells), $p<0.0001$ (Fig. 1B). The cell density of PCL in CA3 was $24.48 \pm 0.31$ cells per $900 \mu \mathrm{m}^{2}$ (mean \pm $\mathrm{SE})$ compared to non-treated rats $(22.13 \pm 0.25$ cells $)$, or saline-treated rats (22.49 \pm 0.39 cells), $\mathrm{p}<0.0001$ (Fig. 1C). The cell density of PCL in CA4 was $20.12 \pm 0.37$ cells per $900 \mu \mathrm{m}^{2}$ (mean \pm SE) compared to non-treated rats (17.78 \pm 0.39 cells $)$, or saline-treated rats $(18.03 \pm 0.35$ cells $)$, $\mathrm{p}<0.0001$ (Fig. 1D). The cell density of GCL in DG was $104.93 \pm 1.12$ cells per $2500 \mu \mathrm{m}^{2}$ (mean \pm SE) compared to non-treated rats $(93.68 \pm 1.33$ cells), or saline-treated rats (95.77 \pm 1.01 cells), $p<0.0001$ (Fig. 1E). The most prominent increase was found at the CA4 area level, as compared to all other 3 areas which were analyzed. The density of pyramidal neurons and glia in all CA subfields was significantly increased by $10.2 \%$ in CA1, $10.6 \%$ in CA3 and $13.2 \%$ in CA4 in CTM treated compared with non treated animals. The density of granule cells and glia in the dentate gyrus was significantly increased by $12.0 \%$ in CTM treated compared with non-treated animals (Fig. 1).

No significant difference of neuronal and glial density was found in any hippocampal subfields in female CTMtreated group compared with the non-treated or saline treated groups (Fig. 2). The cell density of PCL in CA1 was $21.58 \pm$ 0.59 cells per $900 \mu \mathrm{m}^{2}$ (mean \pm SE) compared to non-treated rats $(22.25 \pm 0.58$ cells $)$, or saline-treated rats $(22.63 \pm 0.64$ cells), p>0.05 (Fig. 2B). The cell density of PCL in CA3 was $18.47 \pm 0.32$ cells per $900 \mu \mathrm{m}^{2}$ (mean \pm SE) compared to non-treated rats $(18.15 \pm 0.52$ cells $)$, or saline-treated rats (17.75 \pm 0.34 cells), $p>0.05$ (Fig. 2C). The cell density of PCL in CA4 was $17.22 \pm 0.37$ cells per $900 \mu \mathrm{m}^{2}$ (mean \pm $\mathrm{SE})$ compared to non-treated rats $(16.30 \pm 0.40$ cells $)$, or saline-treated rats (16.67 \pm 0.39 cells), $\mathrm{p}>0.05$ (Fig. 2D). The cell density of GCL in DG was $109.86 \pm 1.30$ cells per $2500 \mu \mathrm{m}^{2}$ (mean $\pm \mathrm{SE}$ ) compared to non-treated rats (109.98 \pm 1.56 cells $)$, or saline-treated rats $(111.28 \pm 1.72$ cells $)$, p>0.05 (Fig. 2E).

\section{DISCUSSION}

Restricted, repetitive behavior, along with deficits in social reciprocity and communication, is diagnostic of autism. Antidepressants use during pregnancy was associated with an increased risk of autism spectrum disorders (Croen et al., 2011; Rai et al., 2013; Boukhris et al., 2016). Animal models based on early life alterations in serotonin availability replicate some of the anatomical and behavioral abnormalities observed in autistic individuals (RodriguezPorcel et al.). For example, early exposure to the serotonin agonist, 5- methoxytryptamine, results in structural alterations in cortical column development and behaviors that include decreased social bonding, sensory-hyperresponsiveness, seizures and motor changes (WhitakerAzmitia). 
A
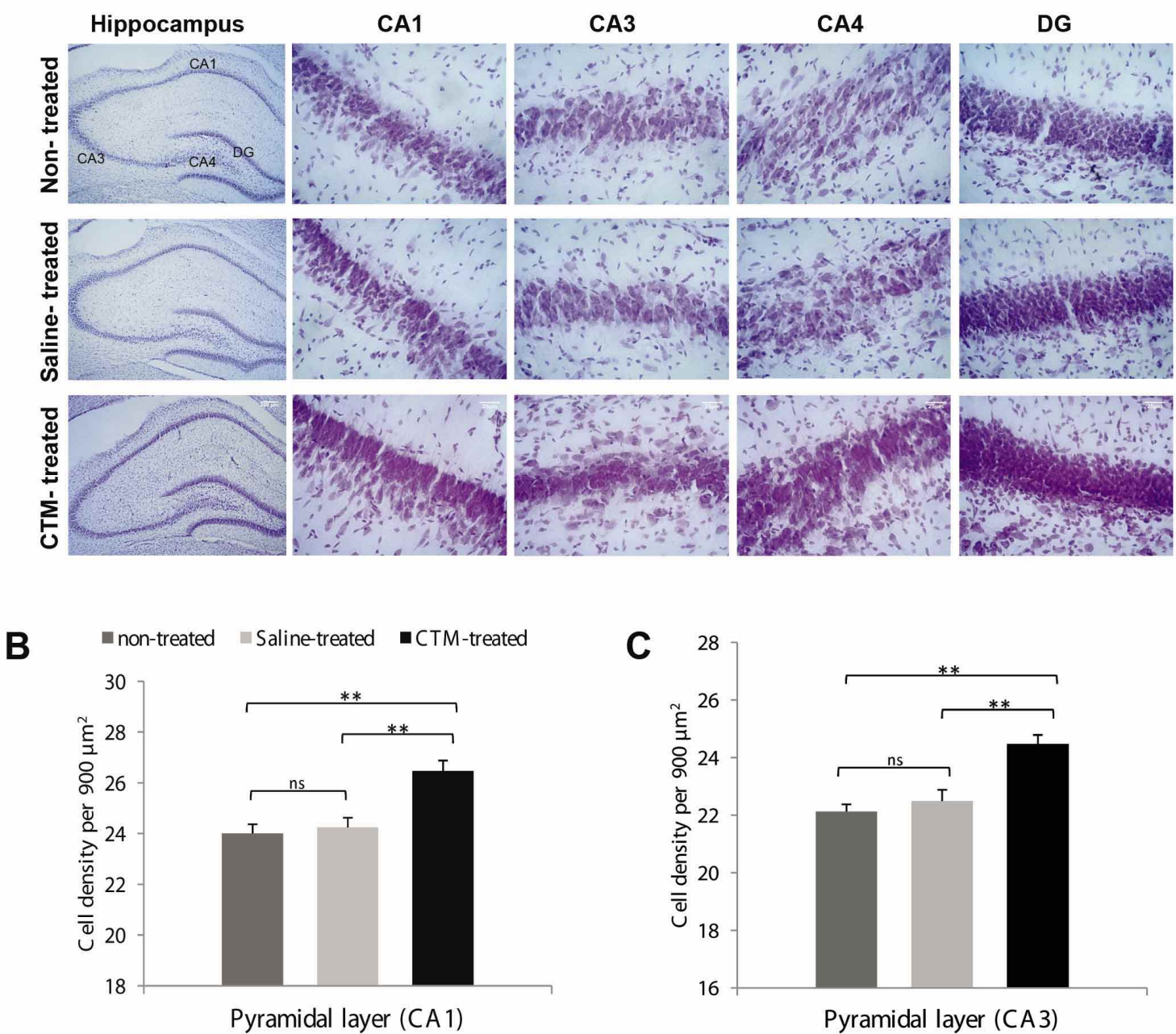

D

E
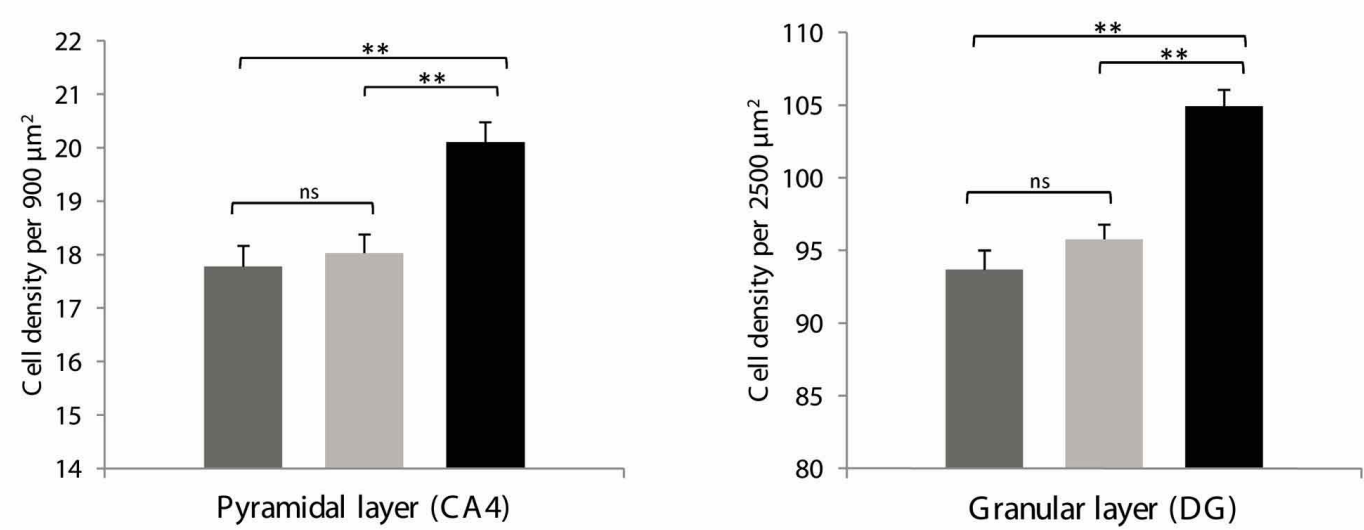

Fig. 1. Representative photomicrographs of nissl stained sections within subdivisions of dorsal hippocampus (CA1, CA3, CA4 and DG) of the three experimental groups (Non-treated, Saline-treated and CTM-treated) in male (A). These images show increases in the cell density in the pyramidal layers of CA1-CA4, and in the granular layer of DG after CTM treatment. There was a distinct increase in staining intensity after CTM treatment. Quantification of the number of the neuronal and glial cell density in pyramidal and granular cell layers within subdivisions of dorsal hippocampus CA1 (B), CA3 (C), CA4 (D) and DG (E) of the three experimental groups. Quantification was done in a test unit of volume $(30 \times 30 \mu \mathrm{m})$ within the pyramidal layer or $(50 \times 50 \mu \mathrm{m})$ within the granular layer. Mean \pm S.E.; ANOVA with post-hoc test: $* * \mathrm{p}<0.001$, ns: non-significant $\mathrm{p}>0.05$. 
A
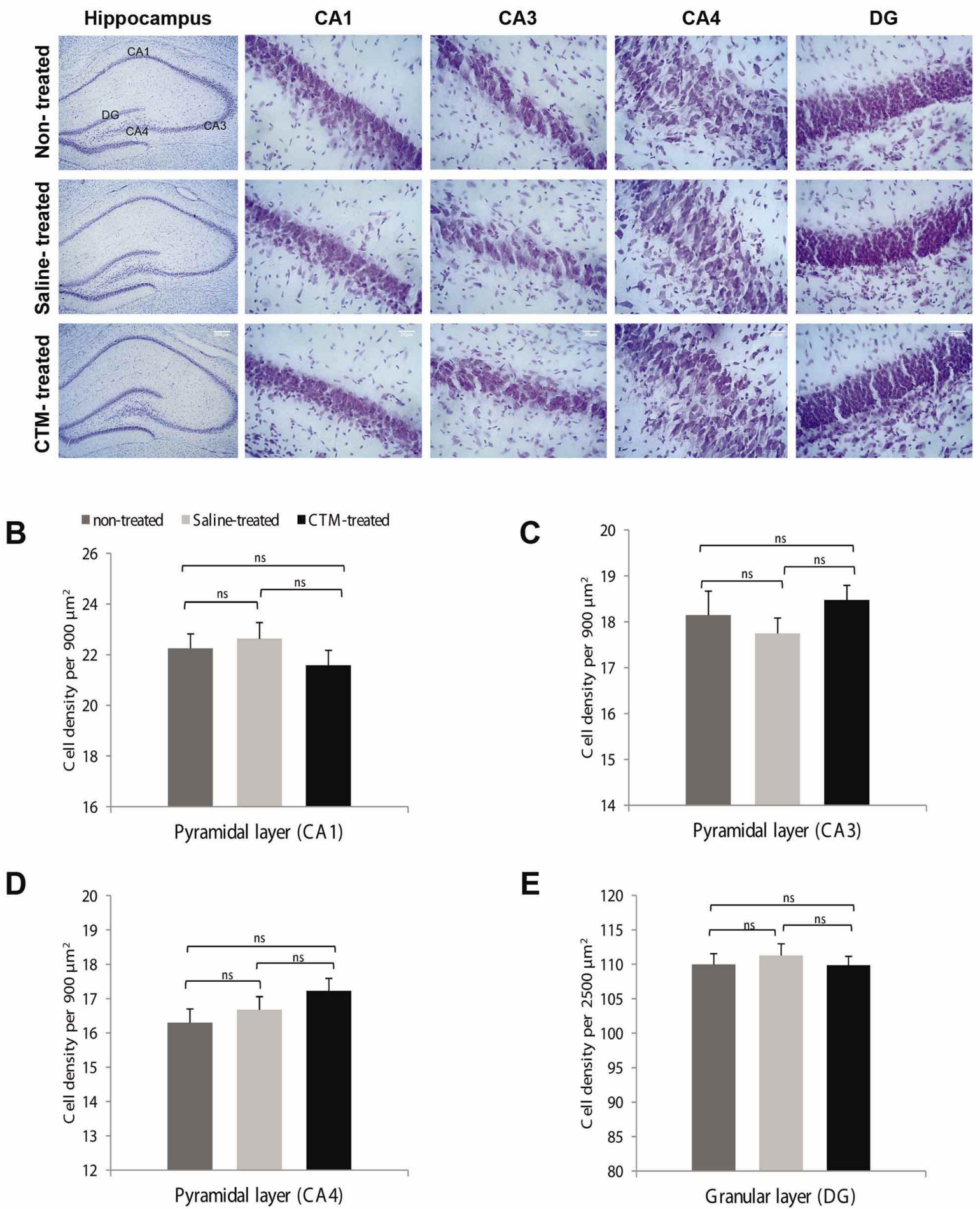

Fig. 2. Representative photomicrographs of Nissl stained sections within subdivisions of dorsal hippocampus (CA1, CA3, CA4 and DG) of the three experimental groups (Non-treated, Saline-treated and CTM-treated) in female (A). These images show no increase in the cell density in the pyramidal layers of CA1-CA4, and in the granular layer of DG after CTM treatment. Quantification of the number of the neuronal and glial cell density in pyramidal and granular cell layers within subdivisions of dorsal hippocampus CA1 (B), CA3 (C), CA4 (D) and DG (E) of the three experimental groups. Quantification was done in a test unit of volume ( $30 \mathrm{x} 30 \mathrm{um})$ within the pyramidal layer or $(50$ x $50 \mathrm{um})$ within the granular layer. Mean \pm S.E.; ANOVA with post-hoc test: ns: non significant p $>0.05$. 
The structural imaging data in ASD patients highlight abnormalities in several brain regions (Salmond et al., 2005; Blatt, 2012). Focal patches of abnormal laminar cytoarchitecture and cortical disorganization of neurons were observed in prefrontal and temporal cortical tissue from postmortem samples obtained from children with autism, suggesting a probable dysregulation of layer formation and layer-specific neuronal differentiation at prenatal developmental stages (Hutsler \& Zhang, 2010; Stoner et al., 2014). Previous studies showed an increased number of minicolumns, combined with fewer cells per column with no difference in neuronal density in post mortem cases of autism (Casanova et al., 2002a,b). Additionally, abnormalities were found in the hippocampus, subiculum, entorhinal cortex, septal nuclei, mamillary body, selected nuclei of the amygdala, neocerebellar cortex, roof nuclei of the cerebellum, and inferior olivary nucleus (Bauman \& Kemper, 2005).

In recent years there has been a growing interest in the possible role of the hippocampus in autism. Studies of postmortem human brains and neuroimaging studies have suggested varying abnormalities in this limbic system structure (Lawrence et al., 2010). The Nissl stained postmortem hippocampus from autistic brains qualitatively demonstrated increased neural density throughout the CA and subicular subfields, with a more flattened appearance of hilar CA4 when compared to controls (Bauman \& Kemper). Furthermore, the density of subsets of hippocampal interneurons, immunostained with the calcium binding proteins, was selectively increased in different subfields of hippocampus of individuals with autism when compared with controls (Lawrence et al.). Other studies reported also abnormalities in the hippocampus in postmortem patients with autism. For example, a Golgi analysis of the CA1 and CA4 regions revealed a decreased complexity and extent of dendritic arbors (Raymond et al., 1996).

In our study, we investigated the effect of early exposure of rat pups to SSRIs (citalopram) on the cell packaging density in the PCL and GCL using Nissl-stained sections obtained from CTM exposed, saline-exposed and control rats. The neuron and glia density was significantly increased in PCL of all CA subfields and the GCL of dentate gyrus. Interestingly, these findings were obtained only from male rats. This sexually dimorphic response in this rodent model is in line with recent reports supporting the notion that male subjects may be more vulnerable to disruptions of the 5-HT system than their female counterparts are, just as ASDs affect males more frequently than females (Hohmann et al., 2007; Rodriguez-Porcel et al.; Simpson et al.; Werling $\&$ Geschwind, 2013). Several sex-differential genetic and hormonal factors may contribute to this prevalence. The action of both androgens and estrogens plays an important role in serotonin metabolism during brain development and adulthood. For example, estrogen interacts with cholinergic and serotonergic systems to affect hippocampal and frontal cortical brain areas and thereby enhance memory (Maki \& Dumas, 2009). In addition, sex steroid hormones are crucial regulators of hippocampal morphology, plasticity, and memory in both male and female rodents (reviewed in Frick et al., 2015). For example, acute stress facilitates classical conditioning and increases apical CA1 dendritic spine density in male rats, but impairs classical conditioning and decreases CA1 spine density in female rats (Wood \& Shors, 1998; Shors et al., 2001). Therefore, males and females may respond differently to various treatments and environmental factors. The possible effects of sex steroid hormones on neural function and behavior should be of special interest for the understanding of the pathophysiological processes underlying ASD.

The increase in cell density of pyramidal and granule cells noticed in this study may be due to serotonin's trophic role in brain development. Serotonin is known to play a trophic role in cell proliferation, migration, and differentiation. Increasing evidence suggests that antidepressants produce structural plasticity in term of numbers of synapses, spines, dendrites, and numbers of cells (Pittenger \& Duman, 2008). Antidepressants increase different aspects of neurogenesis, including the rate of proliferation and the survival of newborn neurons (SegiNishida, 2017).

In conclusion, understanding the impact of early changes in 5-HT levels provides insight into the cellular and physiological basis of neurodevelopmental disorders that underlies behavioral risk. Our results suggest that neonatal exposure of SSRIs during a sensitive period of brain development results in changes in cell density of hippocampal formation in adults and may be useful in understanding the etiology of pervasive developmental disorders such as autism spectrum disorder.

\section{ACKNOWLEDGEMENT}

We gratefully acknowledge the contribution of Rick C. S. Lin (a former member of the University of Mississippi Medical Center, Jackson, MS 39216) for providing the Nissl stained rat brain sections used in this study. The original research (animals, drug application and histological preparation, Rodriguez-Porcel et al.; Weaver et al.; Zhang et al., 2013) was supported by EUREKA MH084194 (RCSL). This research was supported by the Deanship of Scientific Research at The University of Jordan, Amman- Jordan. 
KALBOUNEH, H. M. \& ALZGHOUL, L. A. La exposición neonatal al citalopram aumenta la densidad de las células piramidales y granulares en el hipocampo dorsal de ratas adultas macho pero no en hembras: Un estudio cuantitativo de Nissl. Int. J. Morphol., 37(2):576-583, 2019.

RESUMEN: El uso de antidepresivos durante el embarazo se asoció con un mayor riesgo de trastornos del espectro autista. Los modelos animales basados en alteraciones tempranas de la vida en la disponibilidad de serotonina replican algunas de las anomalías anatómicas y de comportamiento observadas en individuos autistas. En los últimos años ha habido un interés creciente en el posible papel del hipocampo en el autismo. El objetivo del estudio fue examinar los efectos de la exposición al antidepresivo neonatal (CTM) durante un período sensible del desarrollo cerebral en la densidad de las células piramidales y granulares de la formación del hipocampo. Examinamos la densidad de las células piramidales y granulares del hipocampo dorsal utilizando secciones teñidas con Nissl obtenidas de ratas expuestas al citalopram neonatal (CTM) $(5 \mathrm{mg} / \mathrm{kg}$, dos veces al día, sc), desde el día postnatal 8 a 21 (PN8-21), solución salina y ratas no expuestas. La densidad de células piramidales se incrementó significativamente en un 10,2 \% en CA1, 10,6\% en CA3 y 13,2 \% en CA4 en CTM tratados en comparación con animales no tratados o tratados con solución salina $(\mathrm{p}<0,0001)$. La densidad de células granulares en el giro dentado aumentó significativamente en un $12,0 \%$ en los animales tratados con CTM en comparación con los animales no tratados o tratados con solución salina ( $p<0,0001$ ). Estos hallazgos se obtuvieron solo en ratas macho, lo que sugiere un dimorfismo sexual en el desarrollo neural después de la exposición a ISRS. Estos datos sugieren que la exposición neonatal a la CTM puede inducir cambios de larga duración en la formación del hipocampo en adultos, y estos efectos parecen dirigirse preferentemente a los machos.

PALABRAS CLAVE: Antidepresivo; Hipocampo; Autismo; Densidad celular; Citalopram; Exposición neonatal.

\section{REFERENCES}

Bauman, M. L. \& Kemper, T. L. Neuroanatomic observations of the brain in autism: a review and future directions. Int. J. Dev. Neurosci., 23(23):183-7, 2005

Blatt, G. J. The neuropathology of autism. Scientifica (Cairo), 2012:703675, 2012.

Boukhris, T.; Sheehy, O.; Mottron, L. \& Bérard, A. Antidepressant use during pregnancy and the risk of autism spectrum disorder in children. JAMA Pediatr., 170(2):117-24, 2016.

Brackenbury, W. J.; Yuan, Y.; O'Malley, H. A.; Parent, J. M. \& Isom, L. L. Abnormal neuronal patterning occurs during early postnatal brain development of Scn1b-null mice and precedes hyperexcitability. Proc. Natl. Acad. Sci. U. S. A., 110(3):1089-94, 2013.

Casanova, M. F.; Buxhoeveden, D. P.; Switala, A. E. \& Roy, E. Minicolumnar pathology in autism. Neurology, 58(3):428-32, 2002a.

Casanova, M. F.; Buxhoeveden, D. P.; Switala, A. E. \& Roy, E. Neuronal density and architecture (Gray Level Index) in the brains of autistic patients. J. Child. Neurol., 17(7):515-21, 2002b.
Cohen, L. S.; Nonacs, R.; Viguera, A. C. \& Reminick, A. Diagnosis and treatment of depression during pregnancy. CNS Spectr., 9(3):209-16, 2004.

Croen, L. A.; Grether, J. K.; Yoshida, C. K.; Odouli, R. \& Hendrick, V. Antidepressant use during pregnancy and childhood autism spectrum disorders. Arch. Gen. Psychiatry, 68(11):1104-12, 2011.

Ewing, G.; Tatarchuk, Y.; Appleby, D.; Schwartz, N. \& Kim, D. Placental transfer of antidepressant medications: implications for postnatal adaptation syndrome. Clin. Pharmacokinet., 54(4):359-70, 2015.

Frick, K. M.; Kim, J.; Tuscher, J. J. \& Fortress, A. M. Sex steroid hormones matter for learning and memory: estrogenic regulation of hippocampal function in male and female rodents. Learn. Mem., 22(9):472-93, 2015.

Groen, W.; Teluij, M.; Buitelaar, J. \& Tendolkar, I. Amygdala and hippocampus enlargement during adolescence in autism. J. Am. Acad. Child Adolesc. Psychiatry, 49(6):552-60, 2010.

Hohmann, C. F.; Walker, E. M.; Boylan, C. B. \& Blue, M. E. Neonatal serotonin depletion alters behavioral responses to spatial change and novelty. Brain Res., 1139:163-77, 2007.

Homberg, J. R.; Schiepers, O. J.; Schoffelmeer, A. N.; Cuppen, E. \& Vanderschuren, L. J. Acute and constitutive increases in central serotonin levels reduce social play behaviour in peri-adolescent rats. Psychopharmacology (Berl.), 195(2):175-82, 2007.

Hutsler, J. J. \& Zhang, H. Increased dendritic spine densities on cortical projection neurons in autism spectrum disorders. Brain Res., 1309:8394, 2010.

Janusonis, S. Origin of the blood hyperserotonemia of autism. Theor. Biol. Med. Model, 5:10, 2008.

Jennings, K. A.; Loder, M. K.; Sheward, W. J.; Pei, Q.; Deacon, R. M.; Benson, M. A.; Olverman, H. J.; Hastie, N. D.; Harmar, A. J.; Shen, S. \& Sharp, T. Increased expression of the 5-HT transporter confers a low-anxiety phenotype linked to decreased 5-HT transmission. $J$. Neurosci., 26(35):8955-64, 2006.

Lawrence, Y. A.; Kemper, T. L.; Bauman, M. L. \& Blatt, G. J. Parvalbumin, calbindin-, and calretinin-immunoreactive hippocampal interneuron density in autism. Acta Neurol. Scand., 121(2):99-108, 2010.

Lesch, K. P. \& Gutknecht, L. Pharmacogenetics of the serotonin transporter. Prog. Neuropsychopharmacol. Biol. Psychiatry, 29(6):1062-73, 2005.

Maciag, D.; Simpson, K. L.; Coppinger, D.; Lu, Y.; Wang, Y.; Lin, R. C. $\&$ Paul, I. A. Neonatal antidepressant exposure has lasting effects on behavior and serotonin circuitry. Neuropsychopharmacology, 31(1):47-57, 2006.

Maki, P. M. \& Dumas, J. Mechanisms of action of estrogen in the brain: insights from human neuroimaging and psychopharmacologic studies. Semin. Reprod. Med., 27(3):250-9, 2009.

McNamara, I. M.; Borella, A. W.; Bialowas, L. A. \& Whitaker-Azmitia, P. M. Further studies in the developmental hyperserotonemia model (DHS) of autism: social, behavioral and peptide changes. Brain Res., 1189:203-14, 2008.

Mulder, E. J.; Ververs, F. F.; de Heus, R. \& Visser, G. H. Selective serotonin reuptake inhibitors affect neurobehavioral development in the human fetus. Neuropsychopharmacology, 36(10):1961-71, 2011.

Pittenger, C. \& Duman, R. S. Stress, depression, and neuroplasticity: a convergence of mechanisms. Neuropsychopharmacology, 33(1):88109, 2008.

Rai, D.; Lee, B. K.; Dalman, C.; Golding, J.; Lewis, G. \& Magnusson, C. Parental depression, maternal antidepressant use during pregnancy, and risk of autism spectrum disorders: population based case-control study. B. M. J., 346:f2059, 2013.

Raymond, G. V.; Bauman, M. L. \& Kemper, T. L. Hippocampus in autism: a Golgi analysis. Acta Neuropathol., 91(1):117-9, 1996.

Rodriguez-Porcel, F.; Green, D.; Khatri, N.; Harris, S. S.; May, W. L.; Lin, R. C. \& Paul, I. A. Neonatal exposure of rats to antidepressants affects behavioral reactions to novelty and social interactions in a manner analogous to autistic spectrum disorders. Anat. Rec. (Hoboken), 294(10):1726-35, 2011. 
Salmond, C. H.; Ashburner, J.; Connelly, A.; Friston, K. J.; Gadian, D. G. \& Vargha-Khadem, F. The role of the medial temporal lobe in autistic spectrum disorders. Eur. J. Neurosci., 22(3):764-72, 2005.

Samuels, B. A. \& Hen, R. Neurogenesis and affective disorders. Eur. $J$. Neurosci., 33(6):1152-9, 2011.

Sanz, E. J.; De-las-Cuevas, C.; Kiuru, A.; Bate, A. \& Edwards, R. Selective serotonin reuptake inhibitors in pregnant women and neonatal withdrawal syndrome: a database analysis. Lancet, 365(9458):482-7, 2005.

Segi-Nishida, E. The effect of serotonin-targeting antidepressants on neurogenesis and neuronal maturation of the hippocampus mediated via 5-HT1A and 5-HT4 receptors. Front. Cell. Neurosci., 11:142, 2017.

Shors, T. J.; Chua, C. \& Falduto, J. Sex differences and opposite effects of stress on dendritic spine density in the male versus female hippocampus. J. Neurosci., 21(16):6292-7, 2001.

Simpson, K. L.; Weaver, K. J.; de Villers-Sidani, E.; Lu, J. Y.; Cai, Z.; Pang, Y.; Rodriguez-Porcel, F.; Paul, I. A.; Merzenich, M. \& Lin, R. C. Perinatal antidepressant exposure alters cortical network function in rodents. Proc. Natl. Acad. Sci. U. S. A., 108(45):18465-70, 2011.

Stoner, R.; Chow, M. L.; Boyle, M. P.; Sunkin, S. M.; Mouton, P. R.; Roy, S.; Wynshaw-Boris, A.; Colamarino, S. A.; Lein, E. S. \& Courchesne, E. Patches of disorganization in the neocortex of children with autism. N. Engl. J. Med., 370(13):1209-19, 2014.

Vogel, G. W.; Feng, P. \& Kinney, G. G. Ontogeny of REM sleep in rats: possible implications for endogenous depression. Physiol. Behav, 68(4):453-61, 2000.

Weaver, K. J.; Paul, I. A.; Lin, R. C. \& Simpson, K. L. Neonatal exposure to citalopram selectively alters the expression of the serotonin transporter in the hippocampus: dose-dependent effects. Anat. Rec. (Hoboken), 293(11):1920-32, 2010.

Werling, D. M. \& Geschwind, D. H. Sex differences in autism spectrum disorders. Curr. Opin. Neurol., 26(2):146-53, 2013.

Whitaker-Azmitia, P. M. Behavioral and cellular consequences of increasing serotonergic activity during brain development: a role in autism? Int. J. Dev. Neurosci., 23(1):75-83, 2005.

Wood, G. E. \& Shors, T. J. Stress facilitates classical conditioning in males, but impairs classical conditioning in females through activational effects of ovarian hormones. Proc. Natl. Acad. Sci. U. S. A., 95(7):406671, 1998.

Xu, Y.; Sari, Y. \& Zhou, F. C. Selective serotonin reuptake inhibitor disrupts organization of thalamocortical somatosensory barrels during development. Brain Res. Dev. Brain Res., 150(2):151-61, 2004.

Zhang, J.; Dennis, K. A.; Darling, R. D.; Alzghoul, L.; Paul, I. A.; Simpson, K. L. \& Lin, R. C. Neonatal citalopram exposure decreases serotonergic fiber density in the olfactory bulb of male but not female adult rats. Front. Cell. Neurosci., 7:67, 2013.

\author{
Corresponding author: \\ Heba M. Kalbouneh \\ Associate Professor \\ Department of Anatomy and Histology \\ Faculty of Medicine \\ University of Jordan \\ Amman 11942 \\ JORDAN
}

Email: heba.kalbouneh@ju.edu.jo

Received: 04-10-2018

Accepted: 07-01-2019 